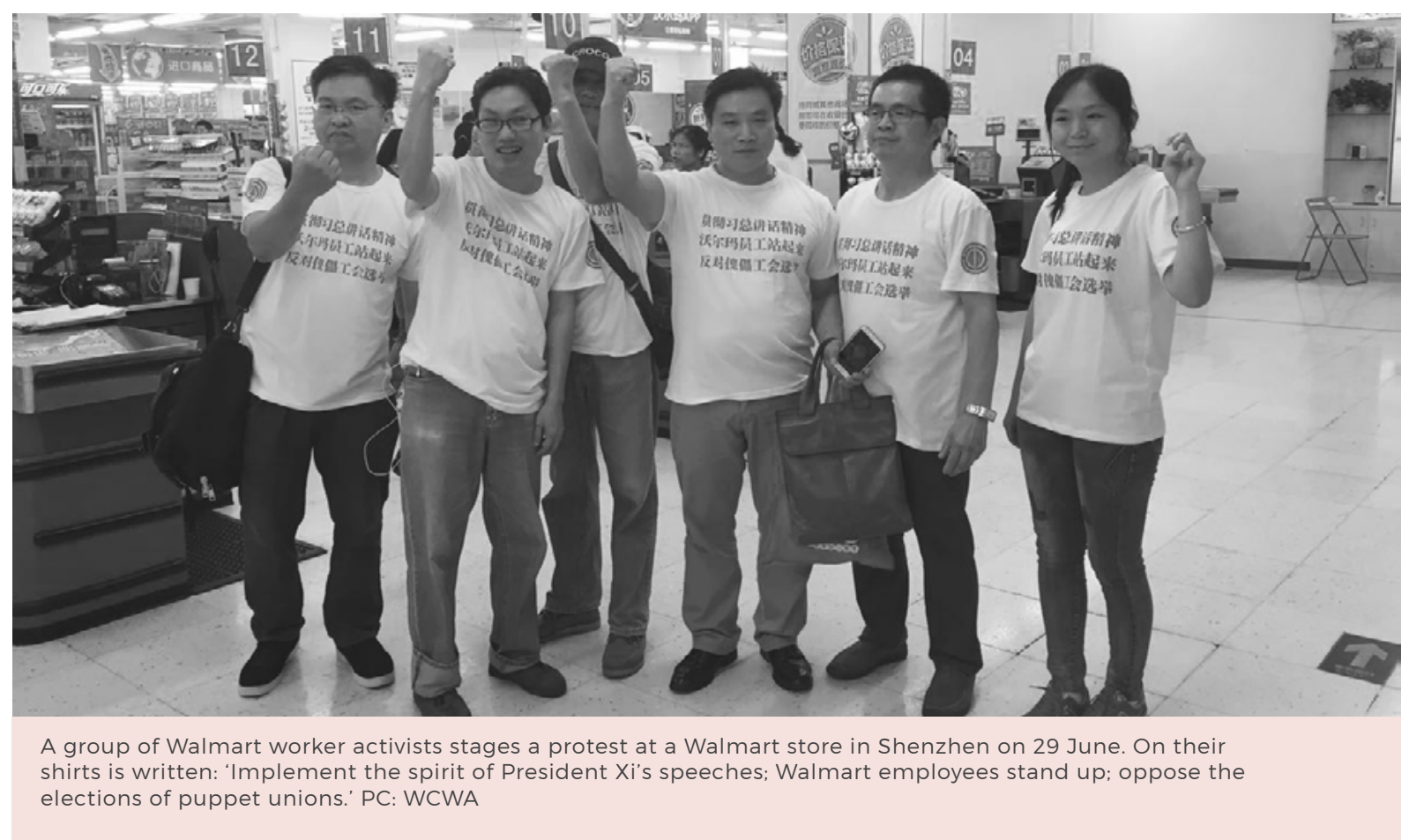

\section{The Resistance of Walmart Workers in China: A Missed Opportunity}

\section{Anita Chan}

Recently, Walmart workers in China joined hands with their international counterparts to move forward in the struggle against the American retail giant. This development has momentous implications for the Chinese labour movement, which is finally linking up with the outside world without going through any intermediary. Yet, this achievement urgently needs international support to be maintained.
On 21 June, the Walmart Chinese Workers' Association (wo'erma zhongguo yuangong lianyihui, WCWA) announced in its blog that it had joined hands in cyberspace with its American counterpart, OUR Walmart (Organisation United for Respect at Walmart), to discuss how to move forward in their struggle against the company. In a show of solidarity, the WCWA also launched a campaign in support of American Walmart workers' fight for a fifteen US dollar minimum wage. This marked a new stage in recent Chinese labour history. This time the news was not about a leader of the AllChina Federation of Trade Unions (ACFTU), the official government trade union, shaking hands with a leader from a foreign trade union. Nor was it Han Dongfang, the wellknown director of the Hong Kong-based China Labour Bulletin, shaking hands with the world's trade union leaders. Instead, a group of workers had themselves, through persistent efforts to break through Chinese walls, finally succeeded in reaching out to co-workers overseas. This appeared to be the culmination of a number of breakthroughs 
over the last decade, but then, after a few months of hard struggle, the movement encountered a setback. In this article, I will outline the background of the struggle of Walmart workers, illustrate its significance, and analyse the causes of its ultimate failure.

\section{Zhang Jun: Electrician and Labour Activist}

Walmart in China has more than four hundred stores in 169 cities, and employs around one hundred thousand people. The WCWA is an online network linking up a large number of Walmart employees across the country. It was set up in 2014 by two Walmart workers: Zhang Jun, an electrician then employed at a Walmart store in Yantai City, Shandong Province, and Zhang Liya, who was working in a store in Shenzhen. Their original intention was to create a platform where Walmart workers could exchange experiences, air grievances, and provide moral support to each other.

Zhang Jun was involved in union organising even before he started working at Walmart. In fact, he had helped organise the first democratically-elected workplace union born out of a strike in China (Chan 2015). The year was 2006. A group of sixty women workers in a small Danish electronics company named Ole Wolff felt aggrieved at the fact that the manager refused to pay social security contributions and agitated to set up their own union. Zhang, the husband of one of these workers, was then a bluecollar worker in a factory nearby and became their legal consultant. They struggled for four years against management and the districtlevel trade union to keep their union going. At one point, Zhang was exchanging texts with one of the ACFTU's deputy chairs, who flew to Shandong to personally instruct the provincial union to recognise the Ole Wolff union. The fight ended in 2010, when Ole Wolff deliberately relocated the factory to South China. In the meantime, Zhang had lost his own job and in March 2011 he became a Walmart worker in his neighbourhood.

\section{6: A Year of Significance}

The chain of events that led to the emergence of the WCWA can be traced back to 2006. At that time, Andy Stern, the president of the

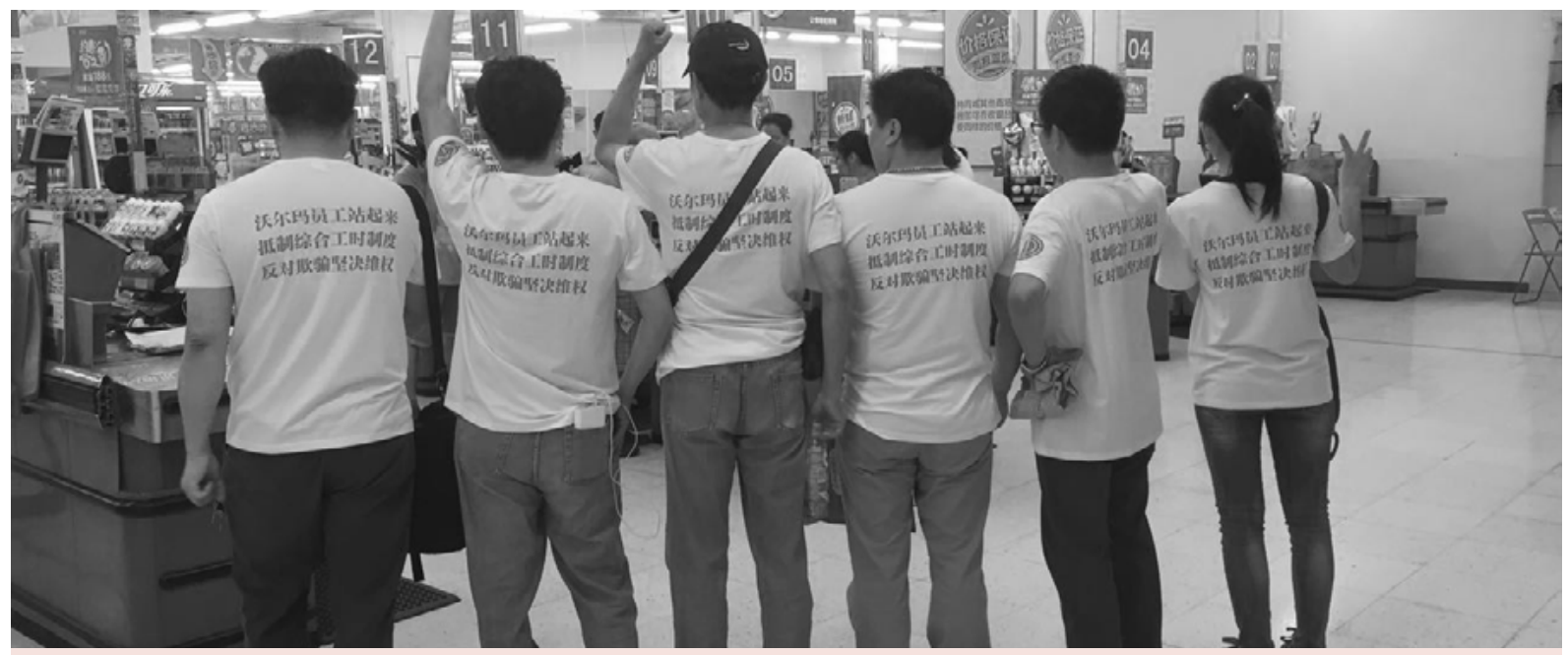

A group of Walmart worker activists stages a protest at a Walmart store in Shenzhen on 29 June. On the back of their shirts is written: 'Walmart employees stand up; boycott the comprehensive working hour system; oppose cheating and keep protecting our rights.' PC: WCWA 
Service Employees International Union, one of the biggest unions in the United States, was launching an international campaign against Walmart. He had come to China a couple of times seeking to persuade the ACFTU to join the global anti-Walmart campaign and it so happened that the ACFTU at the time was under strong pressure from the partystate to contain the rising number of strikes in the country. This instigated the ACFTU to do something that it had not done since the 1950s-organise workers.

Up until that point, whenever it had wanted to set up a branch in a company, the ACFTU had gone directly to the management to establish a workplace union that managers would be able to control. This time, however, the ACFTU experimented with organising Walmart workers 'underground'. In less than two months, the ACFTU was able to set up about one and half dozen Walmart union branches, holding surreptitious night-time union committee elections and founding ceremonies (Chan 2006). But after two months, the ACFTU changed its mind and signed a memorandum of understanding with Walmart, which effectively allowed the company to set up management-controlled unions in more than one hundred stores. Since then, Walmart union branches have been staffed by human resource managers, who have signed so-called 'collective agreements' in the name of the workers (Chan 2011). Yet, as of today the ACFTU still boasts of its high unionisation rate in China's Walmart stores.

Still, the initial spate of democratic elections in 2006 had unintended consequences. Some workers who had participated in those elections wanted to get their unions back. In the following years, when some of the workplace union branches were due for new elections, they fought to register as candidates. Walmart management, with the tacit support of the local unions, put a variety of obstacles in their way. In 2015, Zhang Liya was fired for trying to run. He then sued Walmart, lost the first appeal, and is now waiting for the ruling of the second. In September 2014, Zhang Jun and Zhang Liya decided to establish the WCWA, which grew out of a series of online chat groups in which Walmart workers shared their experiences and gave each other advice on how to deal with problems in their workplaces all over China. In 2016, Zhang Jun quit his job at Walmart.

\section{The Latest Struggle: the 'Comprehensive Working Hour System’}

In mid-May 2016, Walmart announced that it was going to use a 'comprehensive working hour system', which is very similar to American Walmart's 'open work hour system' (see the brief on p. 42 of the present book), allowing extreme flexibility in the allocation of work hours. This meant that there would be no more overtime and thus no more overtime pay, which workers have been relying on to supplement the low income. Suddenly the number of people in the WCWA's online groups jumped to around ten thousand.

Drawing from Zhang Jun's experience at Ole Wolff a decade ago, one of the WCWA's strategies was to hold the trade union responsible for its failure to stop Walmart's flagrant abuse. The WCWA sent appeals for help to different levels of the ACFTU, including two open letters signed by a thousand workers addressed to the union headquarters (WCWA 2016). They also lodged a series of complaints about Walmart's violations of the Chinese labour law and the company's heavy-handedness in forcing workers to sign a consent form for the new working hour system.

Some managers, who were under intense pressure from upper levels of Walmart to collect these signatures, reportedly locked some workers who refused to sign in storage rooms, and threatened them with demotion 
and layoffs. Other workers were inundated by management phone calls and texts, and two workers even suffered mental breakdowns due to the incessant hounding from their superiors.

On 14 June, the Guangdong Province Federation of Trade Unions made a sudden public newspaper statement that a Walmartstyle work hour system can only be used by workplaces that operate a special roster system ( $\mathrm{Xu}$ 2016). Retail stores were not eligible to apply, and using it is a violation of the labour law. Blatantly missing from this statement was any mention of Walmart, or of the fact that some Walmart workers were in rebellion. For a while, it seemed the workers had gained a small victory. But because the union had not taken any concrete action besides these generic declarations (Huang 2016), the announcement did not deter Walmart from continuing to force workers to sign off on the new work hour system.

\section{Strike as the Last Option}

Having exhausted all possible channels to stop Walmart's coercion, workers in a Walmart store in Jiangxi province called 'Nanchang August First Walmart Store' 'fired the first shot'. On 1 July, starting at seven in the morning, seventy workers, all wearing the red Walmart uniforms with protest signs stuck on their backs, went marching up and down the store yelling slogans like 'Boycott Walmart's Comprehensive Working Hours System!' and 'Defend Our Rights to the End!' The news of the strike immediately spread through the WCWA network. Supportive messages poured in and the Nanchang August First Store was hailed as a model store by the aggrieved Walmart workers.

That the first strike broke out in this particular Walmart store is itself of great symbolic significance. 1 August was an important day and place for the city of Nanchang in Chinese Communist history.
That day in 1927 the Nanchang Uprising led by key Chinese Communist Party leaders rose up against the Nationalist Party. The Nanchang Walmart workers prided themselves for having this privilege of starting a rebellion against the world's largest retailer in a store that bears this historically iconic name. They cried in unison: 'At this store, we are carrying on the glorious tradition of the Chinese Communist Party!'

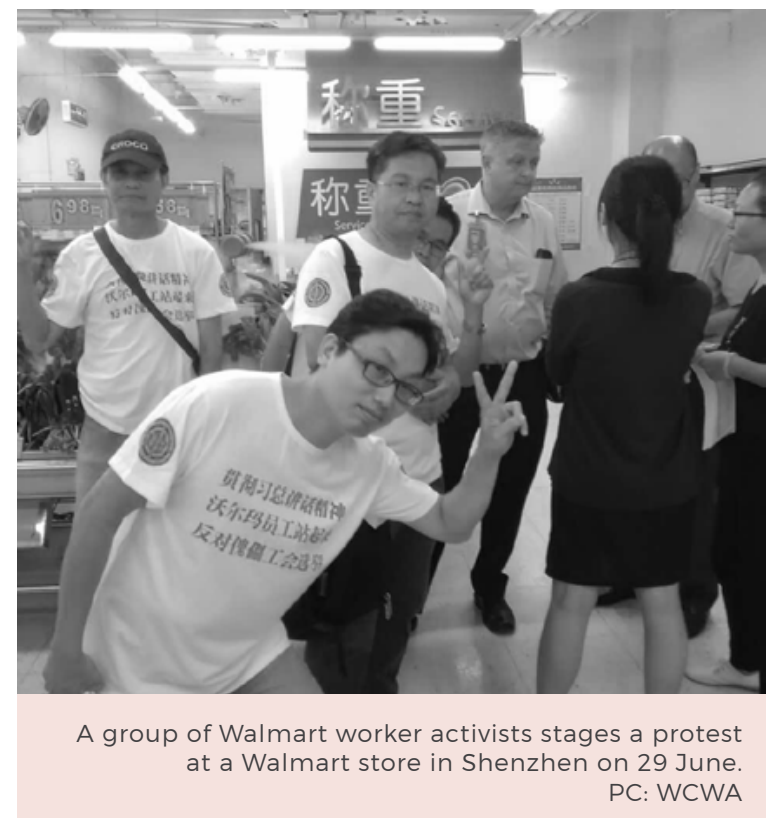

But still why this particular store? Indeed, for Walmart workers in China this store has a glorious past in its own right that has nothing to do with Chinese history. In 2006, this was one of the stores that were able to hold a genuinely democratic union election under the ACFTU's tutelage. An ordinary worker armed with self-taught knowledge of the labour law by the name of Gao Haitao ran as a candidate and was elected as the union chairman (Chan, 2011). He fought with Walmart management over a number of workplace issues. When Walmart issued a blanket collective agreement for all store unions to sign, Gao demanded some changes. The struggle became heated and the news passed upward to the ACFTU headquarters in Beijing. As a model of a courageous trade union chairman, Gao was invited to Beijing to 
meet with high-level union officials, but when he continued to resist signing the collective agreement, the ACFTU abandoned him and, in the end, he was fired. This case was widely reported in the Chinese press (China Labor News Translations 2008).

According to information circulated online in the WCWA network, the Nanchang store today is staffed by a sizeable number of older workers. Some of them must have fought alongside Gao years ago. It is thus not surprising that when the campaign against the new working hour system began, it was workers in this Nanchang store who came out first to declare that none of them had signed nor would sign the consent form.

On the second day of the strike, city authorities finally appeared at the store to find out what the protest was about. They then left and said that they would consider their complaints. In early July, one other store in Nanchang, one in Harbin, and one in Chengdu went on strike. Morale was then high among Walmart workers across the country.

\section{Splits in the Movement}

While activist members of the WCWA were immersed in daily struggle in the stores, some labour NGOs based in Guangdong Province entered the fray. Zhang Zhiru, the leader of a labour NGO based in Shenzhen, was particularly vocal in claiming a leading role in the struggle of Walmart workers. On several occasions, he publicly criticised the two WCWA founders for being too timid and cautious in dealing with the union and the authorities. He encouraged Walmart workers to set up a new group, the 'Walmart Workers Coordinating Committee' (wo'erma yuangong xietiao huiyuanhui), which purportedly would be a structured organisation strong enough to demand Walmart to come to the bargaining table.

Zhang Jun and his colleagues reacted with strong statements warning the members of
WCWA about these attempted 'interferences from external powers' (Wechat 8 July 2016). This split had a devastating effect not only on the morale of the Walmart workers, but also on the relationship among labour NGO activists themselves, who had to take sides with one or the other while they still were right in the middle of one of the worst crackdowns against NGOs in recent history.

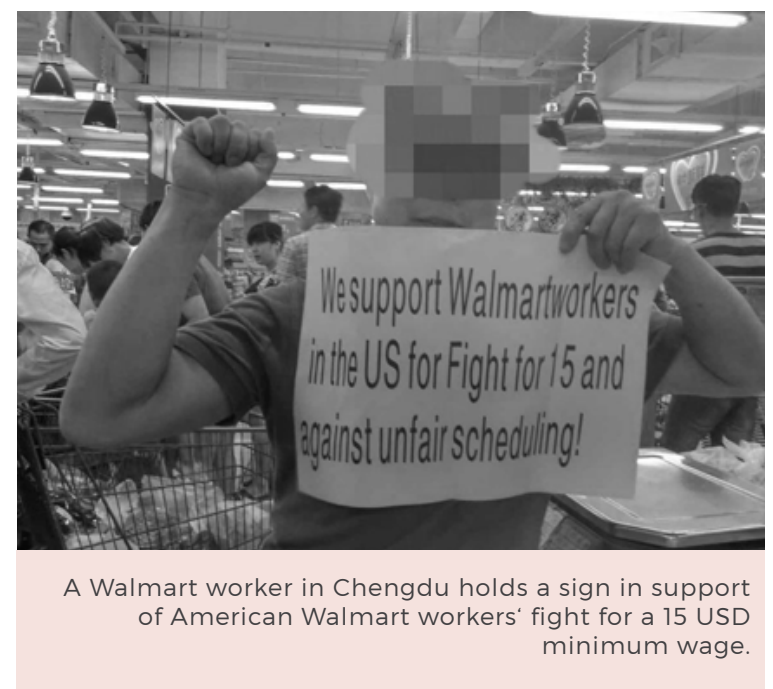

Arguably, behind what at first seemed to be a strategic divergence-Zhang Jun's iajea of cooperating with the unions against Zhang Zhiru's advocacy of a more confrontational type of collective bargaining-is the issue of funding. As international funds are rapidly drying up-a situation that is bound to get worse with the enforcement of the new Foreign NGO Management Law in January 2017 (see the compendium of the Law on pp. 60-67 of the present book)-some NGOs are becoming desperate to find new sources of sustainment. In order to attract the attention of foreign donors and secure their financial support, now more than ever they need to claim credit for workers' struggles, especially in high profile cases.

The open confrontation in the chatrooms between two sides, with a continuous exchange of venomous accusations of greed, official collusion, and corruption, filled the workers with consternation. Participation 
in the WCWA network went into free fall. The damage was so serious that an activist in a labour NGO privately told me that he believed that this clash between workers and NGOs-as well as among NGOs themselvesin the end had done more harm to the labour movement than the government crackdown. Before, labour NGOs were somehow united against a common enemy, now they are rift apart by mutual suspicion.

Taking advantage of this confusion, Walmart went on the offensive, forcing workers to sign the consent form and lashing out at the recalcitrant workers who refused. The retaliation has been relentless,

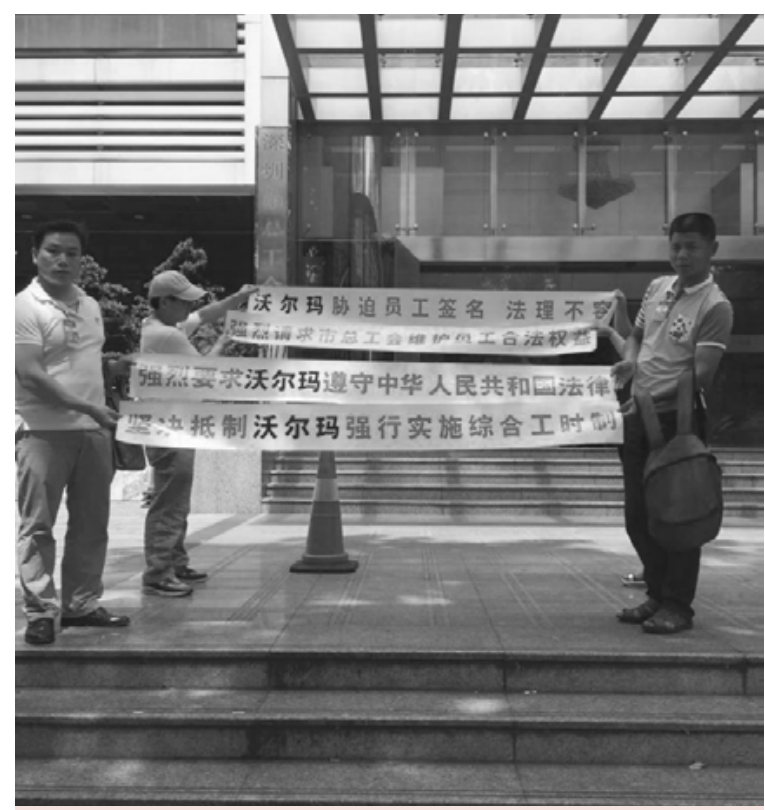

A group of Walmart worker activists stages a protest at a Walmart store in Shenzhen on 29 June.

\section{A Missed Opportunity}

with some employees being fired. The only thing die-hard activists can do now is to try to sue Walmart for wage theft and unfair treatment and dismissal. Despite the initial announcements that Walmart was breeching the law, local unions and the higher echelons of the ACFTU have not lifted a finger to help the workers.
What seemed to be a promising protest movement involving large numbers of workers coordinating on social media collapsed as quickly as it had begun. This exposed the shortcomings in totally relying on the social media as an organising vehicle. Co-ordination is still difficult and unsustainable. But a bigger lesson learned by workers and labour NGOs alike is that foreign funding-as well as the lack thereof-can have a corrosive effect on labour solidarity. Unfortunately, there is every reason to believe that this is bound to get worse in the near future.

\section{Anita Chan}

Anita Chan is Visiting Fellow at the Political and Social Change Department, the Australian National University. Prior to that, she was Research Professor at University of Technology Sydney. Her current research focuses on Chinese labour issues. She has published widely on Chinese workers' conditions, the Chinese trade union, and labour rights issues. On Walmart, she published the edited volume Walmart in China (2011). Her other recent publications include the edited books Labor in Vietnam (2011) and Chinese Workers in Comparative Perspective (2015). 
This text is taken from Disturbances in Heaven: A Year of Chinese Labour, Civil Society, and Rights, Made in China Yearbook 2016, edited by Ivan Franceschini, Kevin Lin and Nicholas Loubere, published 2017 by ANU Press, The Australian National University, Canberra, Australia. 